\title{
Induced Tolerance to Salinity Stress by Halotolerant Bacteria Bacillus aryabhattai H19-1 and B. mesonae H20-5 in Tomato Plants ${ }^{\mathbb{S}}$
}

\author{
Sung-Je Yoo ${ }^{1,2}$, Hang-Yeon Weon ${ }^{1}$, Jaekyeong Song ${ }^{1}$, and Mee Kyung Sang ${ }^{1 *}$ \\ ${ }^{1}$ Division of Agricultural Microbiology, National Institute of Agricultural Science, Rural Development Administration, Wanju 55365, \\ Republic of Korea \\ ${ }^{2}$ Department of Agbiotechnology and Natural Resources, Gyeongsang National University, Jinju 52828, Republic of Korea
}

\author{
Received: April 15, 2019 \\ Revised: June 18, 2019 \\ Accepted: June 19, 2019 \\ First published online \\ June 20, 2019 \\ *Corresponding author \\ Phone: +82-63-238-3055 \\ Fax: +82-63-238-3834; \\ E-mail: mksang@korea.kr
}

\section{S upplementary data for this} paper are available on-line only at http://jmb.or.kr.

pISSN 1017-7825, eISSN 1738-8872

\section{Copyright(C) 2019 by}

The Korean Society for Microbiology and Biotechnology
Salinity is one of the major abiotic stresses that cause reduction of plant growth and crop productivity. It has been reported that plant growth-promoting bacteria (PGPB) could confer abiotic stress tolerance to plants. In a previous study, we screened bacterial strains capable of enhancing plant health under abiotic stresses and identified these strains based on 16s rRNA sequencing analysis. In this study, we investigated the effects of two selected strains, Bacillus aryabhattai $\mathrm{H} 19-1$ and B. mesonae $\mathrm{H} 20-5$, on responses of tomato plants against salinity stress. As a result, they alleviated decrease in plant growth and chlorophyll content; only strain H191 increased carotenoid content compared to that in untreated plants under salinity stress. Strains H19-1 and H20-5 significantly decreased electrolyte leakage, whereas they increased $\mathrm{Ca}^{2+}$ content compared to that in the untreated control. Our results also indicated that $\mathrm{H} 20-5-$ treated plants accumulated significantly higher levels of proline, abscisic acid (ABA), and antioxidant enzyme activities compared to untreated and H19-1-treated plants during salinity stress. Moreover, strain H20-5 upregulated 9-cisepoxycarotenoid dioxygenase 1 (NCED1) and abscisic acid-response element-binding proteins 1 (AREB1) genes, otherwise strain H19-1 downregulated AREB1 in tomato plants after the salinity challenge. These findings demonstrated that strains H19-1 and H20-5 induced ABA-independent and -dependent salinity tolerance, respectively, in tomato plants, therefore these strains can be used as effective bio-fertilizers for sustainable agriculture.

Keywords: Bacillus aryabhattai, B. mesonae, salinity stress, tomato, tolerance

\section{Introduction}

Several environmental factors, such as drought, salinity, water flooding, and extreme high and low temperature can affect plant growth and development; thus reducing crop productivity [1, 2]. Among these stresses, soil salinity is one of the most critical environmental stresses that constrains agricultural productivity [3]. It is known that $20 \%$ of all irrigated agricultural land as well as $10 \%$ of land surface and $50 \%$ of arable land are affected by soil salinity [4]. Furthermore, it is expected that $50 \%$ of the agricultural area will be salinized by 2050 [5]. Therefore, studies on strategies of crop management against salinity stress are essential.
Breeding of new cultivars and stress tolerant plants are studied as common crop management strategies against salinity stress [6]. Moreno-Limon et al. [7] and Mano and Takeda [8] developed salt tolerant cultivars of bean and wheat, respectively, with higher root growth and accumulation of mineral nutrients under salinity stress [9]. Moreover, genetic engineering approaches to improve tolerance to abiotic stress were attempted in rice and tomato by controlling plant signal transduction and regulation of biosynthesis and phytohormone pathway [10, 11]. However, these are long-term strategies, and many governments have not embraced them widely [12]. Therefore, use of microorganisms, including plant growthpromoting bacteria (PGPB) can be an alternative to avoid 
the disadvantages of other strategies [13].

PGPB are well known as free-living soil bacteria that improve plant growth and productivity by increasing nutrient uptake and sustaining soil productivity [14]. Many studies have revealed that they can mitigate plant damage under abiotic stress conditions by the modulation of physiological, biochemical and molecular processes $[15,16$, 17]. Many PGPB can produce 1-aminocyclopropane-1carboxylate (ACC) deaminase which degrades the ethylene precursor ACC thereby alleviating damage by abiotic stress [18]. In addition, some PGPB can also produce indole-3acetic acid (IAA) and affect phosphate solubilization activity. These bacterial traits play pivotal roles in plant growth promotion and mitigation of plant damage by enhancing nutrient absorption under salinity stress condition [19]. Moreover, they can regulate phytohormone synthesis through abscisic acid and antioxidant levels in plants, and alleviate osmotic stress-induced damage [20, 21]. Yang et al. [22] also proposed the term "Induced Systemic Tolerance (IST)", which is a PGPB-induced tolerance by regulating nutrient uptake, ion translocation, phytohormone and reactive oxygen species (ROS) against abiotic stresses in plants. Therefore, PGPB can be one of the possible strategies for alleviating damage by salinity stress. Bacillus vallismortis BS07M was also reported to promote plant growth and reduce soft rot in Chinese cabbages [23]; therefore, in this study, strain BS07M was used as a plant growth-promoting bacterium.

In our previous study, two bacterial strains, Bacillus aryabhattai $\mathrm{H} 19-1$ and $B$. mesonae $\mathrm{H} 20-5$, were selected from among 1,944 strains as bio-fertilizers for alleviation of growth reduction under salinity stress in tomato plants. In this study, we (i) investigated the mitigating effects of two pre-selected bacterial strains on plant growth, pigment and electrolyte leakage in leaves under salinity stress condition; (ii) demonstrated bacterial-mediated salinity tolerant mechanisms including ion content and osmolyte accumulation and (iii) examined bacteria-mediated regulation of ABA metabolism for enhancing stress tolerance in tomato plants. Through these studies, we attempted to understand the changes in plants and mitigating mechanisms of the two bacterial strains, H19-1 and H20-5, under salinity stress in tomato plants.

\section{Materials and Methods}

\section{Plant Materials and Bacterial Treatments}

Tomato (Solanum lycopersicum 'Superdotaerang') seeds were sown into plastic pots (diameter $9 \mathrm{~cm}$ ) containing commercial potting mixture (Bunong, Korea) and grown at room temperature in a greenhouse. Bacterial strains were cultured on tryptic soybean agar (TSA) at $28^{\circ} \mathrm{C}$ for $24 \mathrm{~h}$, and a single colony was cultured in $200 \mathrm{ml}$ of TSB at $28^{\circ} \mathrm{C}, 150 \mathrm{rpm}$ for $48 \mathrm{~h}$. The supernatant was removed after centrifugation at $6,000 \times g$ for $10 \mathrm{~min}$, and cell suspension was adjusted to an $\mathrm{OD}_{600}$ value of 0.25 with $10 \mathrm{mM}$ $\mathrm{MgSO}_{4}$. Bacterial suspensions (1 ml/g of potting mixture) were drenched into the pot-grown, three-week-old tomato seedlings. B. vallismortis BS07M (Bacillo V3, NaproBiotec Inc., Korea) was used as plant growth-promoting bacteria; $10 \mathrm{mM} \mathrm{MgSO}_{4}$ was used as untreated control.

\section{Challenging Salinity Stress}

One week after bacterial treatment, balanced salinity solution $(-1,000 \mathrm{kPa}$, i.e., electrical conductivity (EC) $36.5 \mathrm{mS} / \mathrm{cm}, 1 \mathrm{ml} / \mathrm{g}$ of potting mixture) (as challenging salinity stress) was added to a pot three times at intervals of two days [24]. Non-stressed plants were irrigated only with distilled water $(1 \mathrm{ml} / \mathrm{g}$ of potting mixture). Three weeks after challenging stress, plant growth and parameters including pigment content, electrolyte leakage, ion concentration and osmolyte content were evaluated.

\section{Effect of Strains H19-1 and H20-5 on Growth of Tomato Plants}

Preparation of tomato plants and challenging salinity were followed as described above. Three weeks after challenging salinity stress, plant growth including fresh weight (FW), dry weight (DW) and leaf pigment, such as chlorophyll and carotenoid, were measured. Plants (seven-week old, i.e., ninth to tenth leaf stage) were taken out of soils in pots and roots were washed with running tap water. After removing soils and moisture, total fresh weight was measured. For dry weight, plants were dried at $60^{\circ} \mathrm{C}$ for three days and estimated. For measurement of chlorophyll and carotenoid content, sampled leaves were treated with $80 \%$ acetone (v/v) containing $0.5 \%$ (wt. $/ \mathrm{v}) \mathrm{MgCO}_{3}$ overnight at $4^{\circ} \mathrm{C}$ to prevent chlorophyll acidification. The crude extract was used to measure chlorophyll content according to the method of Lichtenthaler [25] using a UV/VIS spectrophotometer (Infinite M200 PRO, TECAN, Austria). Chlorophyll a, b, and carotenoid content were calculated as follows:

$$
\begin{aligned}
& \text { Chlorophyll } a=\left(12.25 \times A_{663.2}\right)-\left(2.79 \times A_{646.8}\right) \\
& \text { Chlorophyll } b=\left(21.50 \times A_{646.8}\right)-\left(5.10 \times A_{663.2}\right) \\
& \text { Total chlorophyll content }=\text { chlorophyll } a+\text { chlorophyll b } \\
& \text { Carotenoid concentration }=\left[\left(1,000 \times A_{470}\right)-(1.8 \times \text { chlorophyll } a)-\right. \\
& (85.02 \times \text { chlorophyll } b)] / 198
\end{aligned}
$$

Changes in Electrolyte Leakage, Ion Concentration, Free Proline,

\section{Total Soluble Sugar and Free Amino Acid}

For measurement of electrolyte leakage, a method of Lutts $e t$ al. [26] was used with modifications by Shukla et al. [27]. Leaves were cut and washed with deionized water to remove electrolytes 
adhering to the leaf surface. The washed leaves were transferred into test tubes containing $10 \mathrm{ml}$ of deionized water, and the leaves were incubated at $25^{\circ} \mathrm{C}$ for $24 \mathrm{~h}$. Electrical conductivity (EC) of the solution $\left(\mathrm{L}_{\mathrm{t}}\right)$ was measured, and the samples were autoclaved at $121^{\circ} \mathrm{C}$ for $20 \mathrm{~min}$. After cooling at room temperature, the final EC $\left(\mathrm{L}_{0}\right)$ was detected. Electrolyte leakage $(\%)$ was calculated as follows:

Electrolyte leakage $=\left(L_{t} / L_{0}\right) \times 100$

For measurement of ion content in tomato leaves, $\mathrm{Na}^{+}, \mathrm{K}^{+}$, and $\mathrm{Ca}^{2+}$ ion meters (LAQUAtwin, Japan) were used as described by Iseki et al. [28]. Similar-sized plant leaves (50-65 mg) were sampled and dried at $70^{\circ} \mathrm{C}$ for three days. The dried leaves were weighed and homogenized using Retsch MM200 Mixer (RetshTM, Germany). After adding $1 \mathrm{ml}$ of distilled water, the samples were incubated at $150 \mathrm{rpm}$ for $1 \mathrm{~h}$, spun down at 7,000 $\times \mathrm{g}$ for $5 \mathrm{~min}$, and the supernatant was used for measuring ion content.

Free proline content in plant leaves was estimated by a ninhydrin test [29]. Plant leaves (100 $\mathrm{mg}$ ) were homogenized in $1.2 \mathrm{ml}$ of $3 \%$ sulfosalicylic acid, and samples were centrifuged at 13,000 $\times g$ for $10 \mathrm{~min}$. Supernatant $500 \mu \mathrm{l}$ was mixed with $500 \mu \mathrm{l}$ of glacial acetic acid and $500 \mu \mathrm{l}$ of acidic ninhydrin, and then the mixture was heated at $90^{\circ} \mathrm{C}$ for $1 \mathrm{~h}$. The samples were cooled in ice and $1 \mathrm{ml}$ of toluene was added. After vortexing, the upper phase showed absorbance at $520 \mathrm{~nm}$.

For measurement of total soluble sugar and free amino acid, leaf (1 g) was extracted with methanol-chloroform-water (60:25:15 $\mathrm{v} / \mathrm{v})$ at $60^{\circ} \mathrm{C}$ for $2 \mathrm{~h}$. After centrifugation at $10,000 \times g$ for $10 \mathrm{~min}$, the supernatant was used to estimate total soluble sugar content by anthrone-sulfuric acid method [30]. Total free amino acid content was measured according to the method of Chen et al. [31] using a ninhydrin test. Next, $0.1 \mathrm{M}$ sodium acetate acetic buffer $(\mathrm{pH}=4.3,1 \mathrm{ml})$ and $5 \%$ ninhydrin agent $(1 \mathrm{ml})$ were added in the plant extract $(1 \mathrm{ml})$ and the mixture was heated immediately at $95^{\circ} \mathrm{C}$ for $15 \mathrm{~min}$. The samples were cooled at room temperature and absorbance was read at $570 \mathrm{~nm}$.

\section{Antioxidant Enzyme Activities and ABA Accumulation}

Enzyme activities of catalase (CAT), superoxide dismutase (SOD), and glutathione peroxidase (GPx) were determined six days after challenging stress. For measurement of CAT activity, $1 \mathrm{~g}$ of frozen leaves were homogenized in $5 \mathrm{ml}$ of cold $50 \mathrm{mM}$ potassium phosphate buffer $(\mathrm{pH}=7.0)$ containing $1 \mathrm{mM}$ EDTA and then centrifuged at $12,000 \times g$ for $15 \mathrm{~min}$ at $4^{\circ} \mathrm{C}$. CAT activity was measured in the supernatant with a catalase assay kit (Item no. 707002, Cayman Chemical Company, USA). For measurement of SOD activity, $1 \mathrm{~g}$ of frozen leaves were homogenized in $5 \mathrm{ml}$ of cold $20 \mathrm{mM}$ HEPES buffer ( $\mathrm{pH}=7.2$ ) containing $1 \mathrm{mM}$ EGTA, $210 \mathrm{mM}$ mannitol and $70 \mathrm{mM}$ sucrose. After centrifuging at $12,000 \times g$ for $15 \mathrm{~min}$ at $4^{\circ} \mathrm{C}$, supernatant was used to estimate SOD enzyme activity by using a superoxide dismutase assay kit (Item no. 706002, Cayman Chemical Company). GPx activity was measured using glutathione peroxidase assay kit (item no. 703102, Cayman Chemical Company). One milliliter of homogenization buffer (50 mM Tris-HCl, pH 7.5, 5 mM EDTA and 1 mM DTT) was added per $100 \mathrm{mg}$ of frozen leaves and homogenized. After spinning down at $12,000 \times g$ for $15 \mathrm{~min}$ at $4^{\circ} \mathrm{C}$, supernatant was used. ABA content in plant leaves was tested by the enzymelinked immunosorbent assay (ELISA) with an ABA test kit (Cat. No. PDK 09347/0096, Agdia Inc., USA) following the manufacturer's instructions and methodology described by Iovieno et al. [32].

\section{Gene Expression Analysis}

Tomato leaves were collected and frozen by liquid nitrogen at 6 , 24 and $48 \mathrm{~h}$ after challenging stress. The tissues were homogenized using a Retsch MM200 Mixer Model Mill (RetshTM) and total RNA was extracted using a plant RNA extraction kit (iNtRON, Korea) according to the manufacturer's instructions. For the quantitative reverse transcription polymerase chain reaction (qRT-PCR), complementary DNA (cDNA) was synthesized using the PrimeScript RT Master Mix (Cat. No. RR036A, Takara). qRTPCR analysis performed with $20 \mu$ of reaction mixture containing $3 \mu \mathrm{l}$ cDNA ( $10 \%$ of the first-strand reaction), $1 \mu \mathrm{l}$ of each primer (5 pmol), and $2 \times$ SYBR reaction buffer (TOPreadTM qPCR 2× PreMIX, Enzynomics, Korea). Amplification was carried out using a CFX96 Real-Time PCR Detection System (Bio-Rad, USA) and an initial denaturation step was performed at $95^{\circ} \mathrm{C}$ for $10 \mathrm{~min}$, followed by 40 cycles for $15 \mathrm{sec}$ at $95^{\circ} \mathrm{C}, 20 \mathrm{sec}$ at $58^{\circ} \mathrm{C}$, and $18 \mathrm{sec}$ at $72^{\circ} \mathrm{C}$. For quantification of relative gene expression, primer sequences of the genes related to ABA-dependent pathway (9-cisepoxycarotenoid dioxygenase 1 (NCED1) and abscisic acid-response element-binding proteins (AREB1)) are listed in Table S1. Actin was utilized as reference gene described by Løvdal and Lillo [33] and the relative gene expression levels were evaluated using $2^{-\Delta \Delta c t}$ method [34].

\section{Statistical Analysis}

Statistical analysis of the data obtained was performed using Statistical Analysis System (SAS) (version 9.1.3, SAS Institute Inc., Cary, NC). Plant growth, leaf pigment, electrolyte leakage, ion content and osmolyte tests were conducted with 12 replications from two experiments; for antioxidant enzyme activities, ABA accumulation, and gene expression analysis eight replications were conducted from two experiments. Pooled data from repeated experiments were used for statistical analysis after confirmation of homogeneity of the variances by Leven's test. Analysis of variance was performed using the general linear model (GLM), and the means were separated by the least significant difference (LSD), or Tukey's tests at $p<0.05$.

\section{Results}

\section{Strains H19-1 and H20-5 Promote Plant Growth and Leaf Pigment Content under Salinity Stress}

Three weeks after the salinity stress challenge in tomato plants, growth inhibition was observed in stressed plants 
A

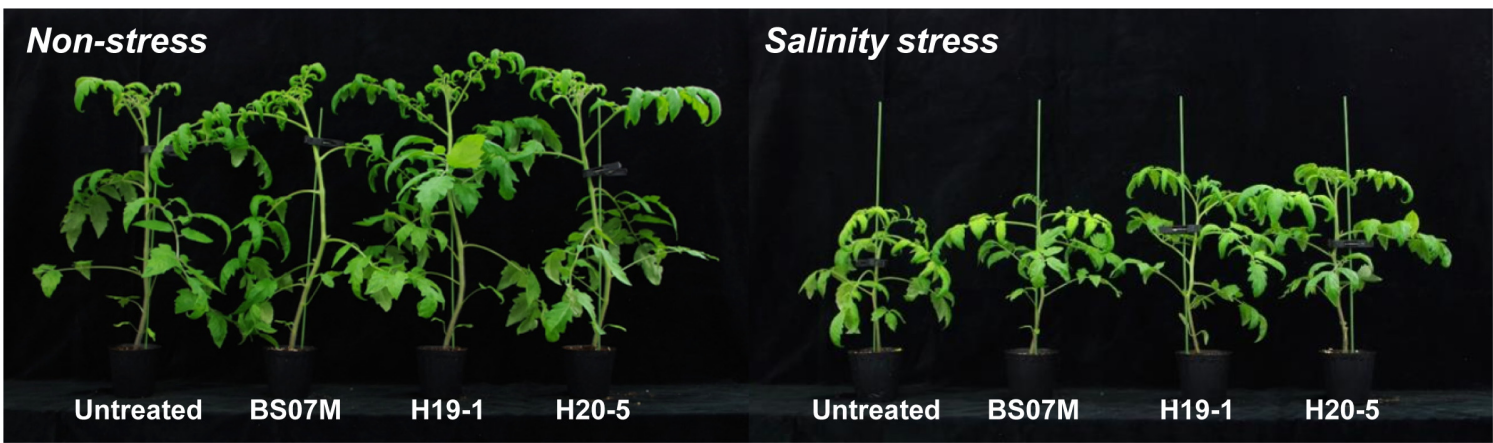

\section{B}

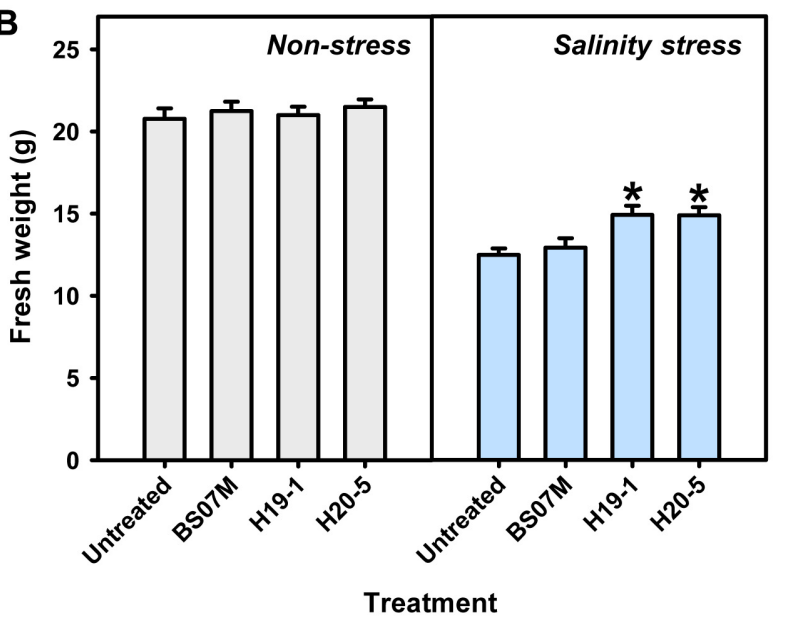

C

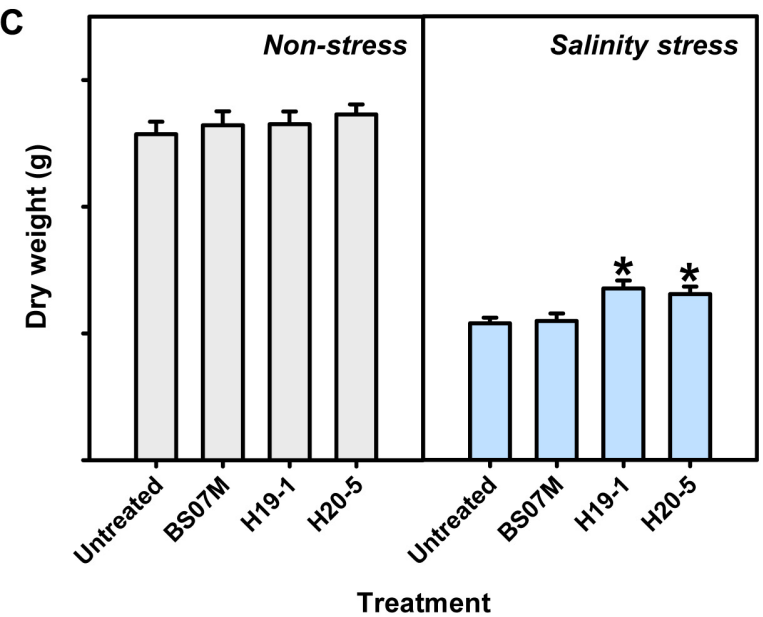

Fig. 1. The effects of B. aryabhattai H19-1 and B. mesonae H20-5 on (A) growth, (B) fresh weight, and (C) dry weight in tomato plants under non- and salinity stresses.

Bacterial suspensions and $10 \mathrm{mM} \mathrm{MgSO}_{4}$ (untreated) were drenched into tomato plants grown for three weeks in a greenhouse. One week after treatments, water (for non-stress) or salinity solutions (for stress) were drenched into plants; three weeks after salinity stress challenge, plant growth was measured. Asterisks on the bar mean statistical difference by the LSD test at $p<0.05$; error bars indicate standard error.

compared to non-stressed (Fig. 1, fresh weight (FW): $p<$ 0.0001; dry weight (DW): $p<0.0001)$. In non-stressed plants, fresh weight was not significantly different between untreated and bacteria-treated plants (Fig. 1B, $p=0.8124$ ). However, compared to plants under salinity stress, both bacterial strains, H19-1 and H20-5 led to an increase of 20\% and $19 \%$, respectively, in fresh weight $(p=0.0014)$. Similarly, the dry weight of plants treated with the two bacterial strains, H19-1 and H20-5, was 25\% and 21\%, respectively, higher than that of untreated plants under salinity stress,

Table 1. Total chlorophyll and carotenoid content in leaves of tomato plants treated with $10 \mathrm{mM} \mathrm{MgSO}_{4}$ (untreated) or bacterial suspensions under non- and salinity stresses.

\begin{tabular}{|c|c|c|c|c|}
\hline \multirow{2}{*}{ Treatment } & \multicolumn{2}{|c|}{ Chlorophyll content ( $\mu \mathrm{g} / \mathrm{g}$ FW) } & \multicolumn{2}{|c|}{ Carotenoid content ( $\mu \mathrm{g} / \mathrm{g}$ FW) } \\
\hline & Non-stress & Salinity stress & Non-stress & Salinity stress \\
\hline Untreated & $137.5 \pm 3.4^{\mathrm{a}}$ & $118.7 \pm 1.6$ & $29.5 \pm 0.7$ & $23.0 \pm 0.8$ \\
\hline BS07M & $135.8 \pm 5.8$ & $113.4 \pm 2.8$ & $28.8 \pm 1.0$ & $23.2 \pm 0.5$ \\
\hline H19-1 & $153.2 \pm 7.1^{*}$ & $131.1 \pm 2.0^{*}$ & $34.1 \pm 2.1^{*}$ & $26.4 \pm 0.4^{*}$ \\
\hline H20-5 & $146.0 \pm 2.8$ & $127.0 \pm 3.7^{*}$ & $33.0 \pm 1.7$ & $23.5 \pm 0.9$ \\
\hline
\end{tabular}

${ }^{a}$ The values are mean \pm standard errors of 12 replications from two experiments. An asterisk indicates a statistical difference $(p<0.05)$ compared to untreated plants in a column by the LSD test. 
whereas no significant difference was observed in nonstressed plants (Fig. 1C, non-stressed plants: $p=0.7493$; salinity-stressed plants: $p=0.0013$ ). Photosynthetic pigments containing chlorophyll and carotenoid content were decreased in stressed plants compared to that in nonstressed plants (Table 1, chlorophyll content: $p<0.0001$; carotenoid content: $p<0.0001)$. The pigment content of plants treated with H19-1 was higher than that of untreated plants under non-stressed condition (chlorophyll content: $p=0.0455$; carotenoid content: $p=0.0377)$. Moreover, significant increase of chlorophyll content was observed in plants treated by both strains under salinity stress while only H19-1 significantly elevated carotenoid content in stressed plants (chlorophyll content: $p=0.0008$; carotenoid content: $p=0.0078)$.

\section{Strains H19-1 and H20-5 Decrease Electrolyte Leakage} and Increase $\mathrm{Ca}^{2+}$ Content under Salinity Stress

To investigate the influence of bacterial treatment on plant biochemical properties under salinity stress, electrolyte leakage, and high ion concentrations including those of $\mathrm{Na}^{+}, \mathrm{K}^{+}$, and $\mathrm{Ca}^{2+}$ were evaluated in plant leaves. Our present study indicated that salinity stress led to an increase in electrolyte leakage in plant leaves compared to non-stressed plants (Fig. 2, $p<0.0001$ ). Moreover, treatment of H19-1 and H20-5 decreased electrolyte leakage in plants by $15 \%$ and $17 \%$, while untreated plants showed $36 \%$

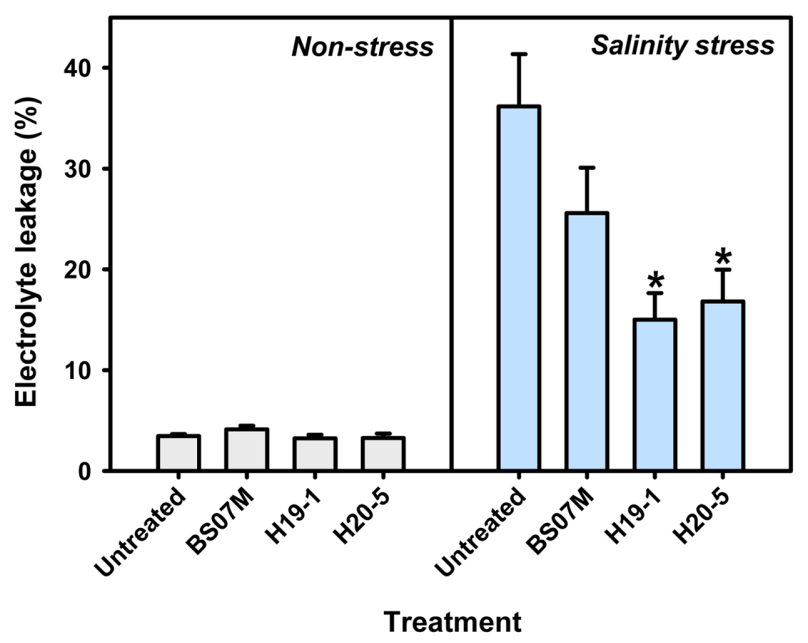

Fig. 2. The effects of B. aryabhattai H19-1 and B. mesonae H20-5 on electrolyte leakage (\%) in tomato leaves under non- and salinity stresses.

Leaves were sampled at three weeks after the salinity stress challenge. Asterisks on the bar mean statistical difference by the LSD test at $p<0.05$ and error bars indicate standard error. electrolyte leakage under salinity stress $(p=0.0073)$. Under non-stress condition, no evident difference between untreated and bacteria-treated plants was observed $(p=$ 0.2564). Concentration of $\mathrm{Na}^{+}$in non-stressed and stressed
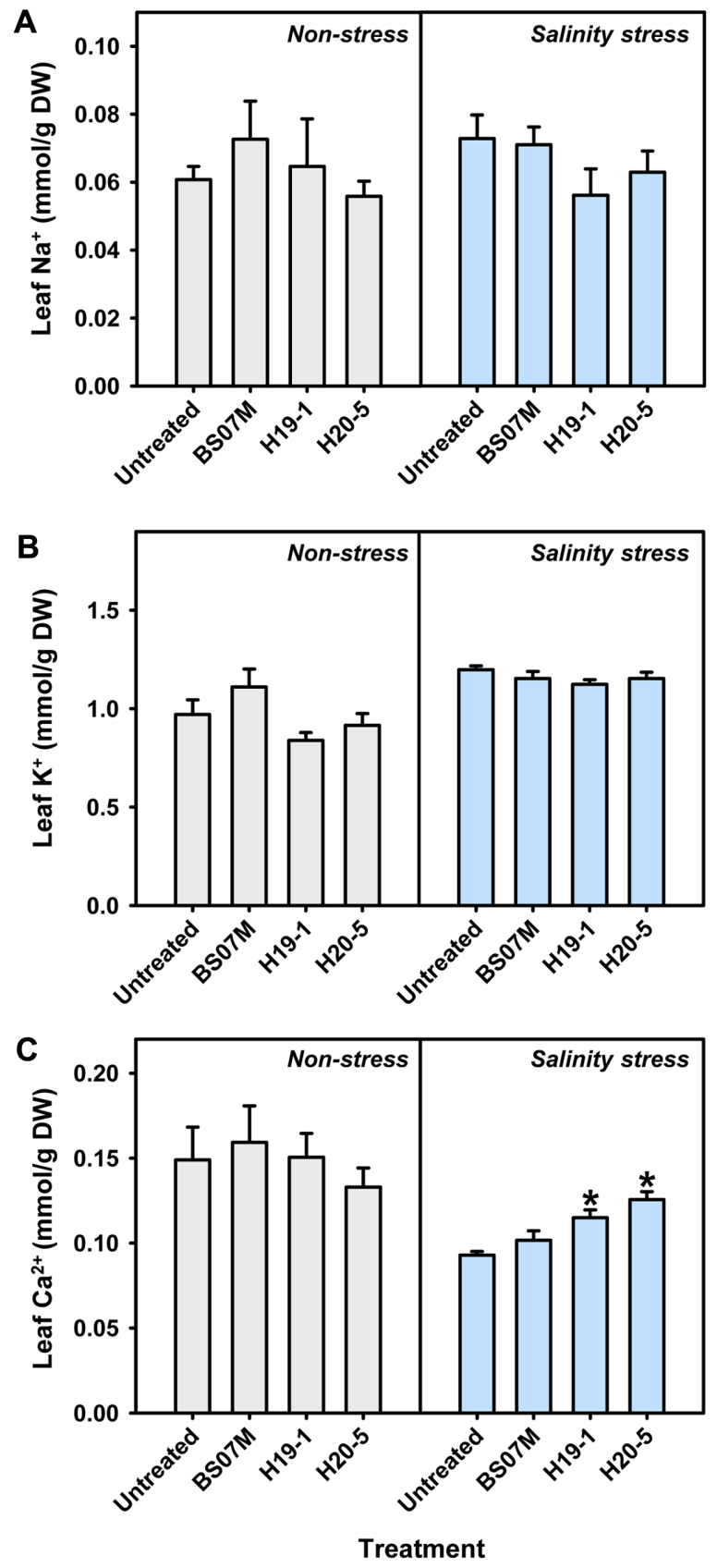

Fig. 3. The effects of B. aryabhattai $\mathrm{H} 19-1$ and B. mesonae $\mathrm{H} 20-5$ on (A) $\mathrm{Na}^{+},\left(\right.$B) $\mathrm{K}^{+}$, and (C) $\mathrm{Ca}^{2+}$ contents (mmol/g DW) in tomato leaves under non- and salinity stresses.

Leaves were sampled at three weeks after salinity stress challenge. Asterisks on the bar mean significant difference by the LSD test at $p<$ 0.05 ; error bars indicate standard error. 
plants did not show any evident difference, whereas stress challenge led to an increase in $\mathrm{K}^{+}$concentration $\left(\mathrm{Na}^{+}\right.$ content: $p=0.6243 ; \mathrm{K}^{+}$content: $\left.p=0.0001\right)$. In addition, there was no significant difference in these concentrations between untreated and bacteria-treated plants under both conditions (Figs. 3A and 3B, $\mathrm{Na}^{+}$(non-stressed plants): $p=$ 0.6298; $\mathrm{Na}^{+}$(salinity-stressed plants): $p=0.2731 ; \mathrm{K}^{+}$(nonstressed plants): $p=0.0802 ; \mathrm{K}^{+}$(salinity-stressed plants): $p=$ $0.4355)$. In contrast to $\mathrm{Na}^{+}$and $\mathrm{K}^{+}$concentration, salinity stress led to a decrease in $\mathrm{Ca}^{2+}$ concentration in plant leaves compared to that in non-stressed plants $(p<0.0001)$. Moreover, $\mathrm{Ca}^{2+}$ concentrations in tomato plants treated with $\mathrm{H} 19-1$ and $\mathrm{H} 20-5$ were $24 \%$ and $35 \%$ higher than that in untreated plants in salinity-stressed plants but not in non-stressed plants (Fig. 3C, non-stressed plants: $p=0.7346$; salinity-stressed plants: $p=0.0003)$.

Strain H20-5 Accumulates Proline in Tomato Plants but Did Not Affect Total Soluble Sugar and Free Amino Acid under Salinity Stress

To demonstrate the effect of bacterial strains on osmoprotection in plants, contents of proline, total soluble sugar and free amino acid were measured. As a result, stress challenge led to proline accumulation in plants compared to non-stressed plants (Table 2, $p<0.0001$ ). Moreover, proline content was significantly accumulated in plants treated with $\mathrm{H} 20-5$ compared to that in untreated plants under salinity stress, whereas strains BS07M and H19-1 did not affect tproline content in plants ( $p=0.0410)$. In non-stressed condition, changes in proline content were not observed $(p=0.6345)$. Total soluble sugar and free amino acid contents in plants were also decreased under salinity stress (total soluble sugar: $p<0.0001$; free amino acid: $p<0.0001)$. However, there was no significant difference between untreated and bacteria-treated plants in both non-stressed and stressed conditions (total soluble sugar (non-stressed plants): $p=0.8565$; total soluble sugar (stressed plants): $p=0.8251$; free amino acid (non-stressed plants): $p=0.6303$; free amino acid (stressed plants): $p=$ 0.7574).

\section{Strain H20-5 Enhances Antioxidant Enzyme Activities during Salinity Stress}

To examine the mitigative effect of bacterial treatment on oxidative damage in plants, antioxidant enzymes activities were evaluated. Three antioxidant enzyme activities were increased in plants in salinity stress conditions, compared to those in non-stressed conditions (Fig. 4, catalase (CAT): $p<0.0001$; superoxide dismutase (SOD): $p<0.0001$;
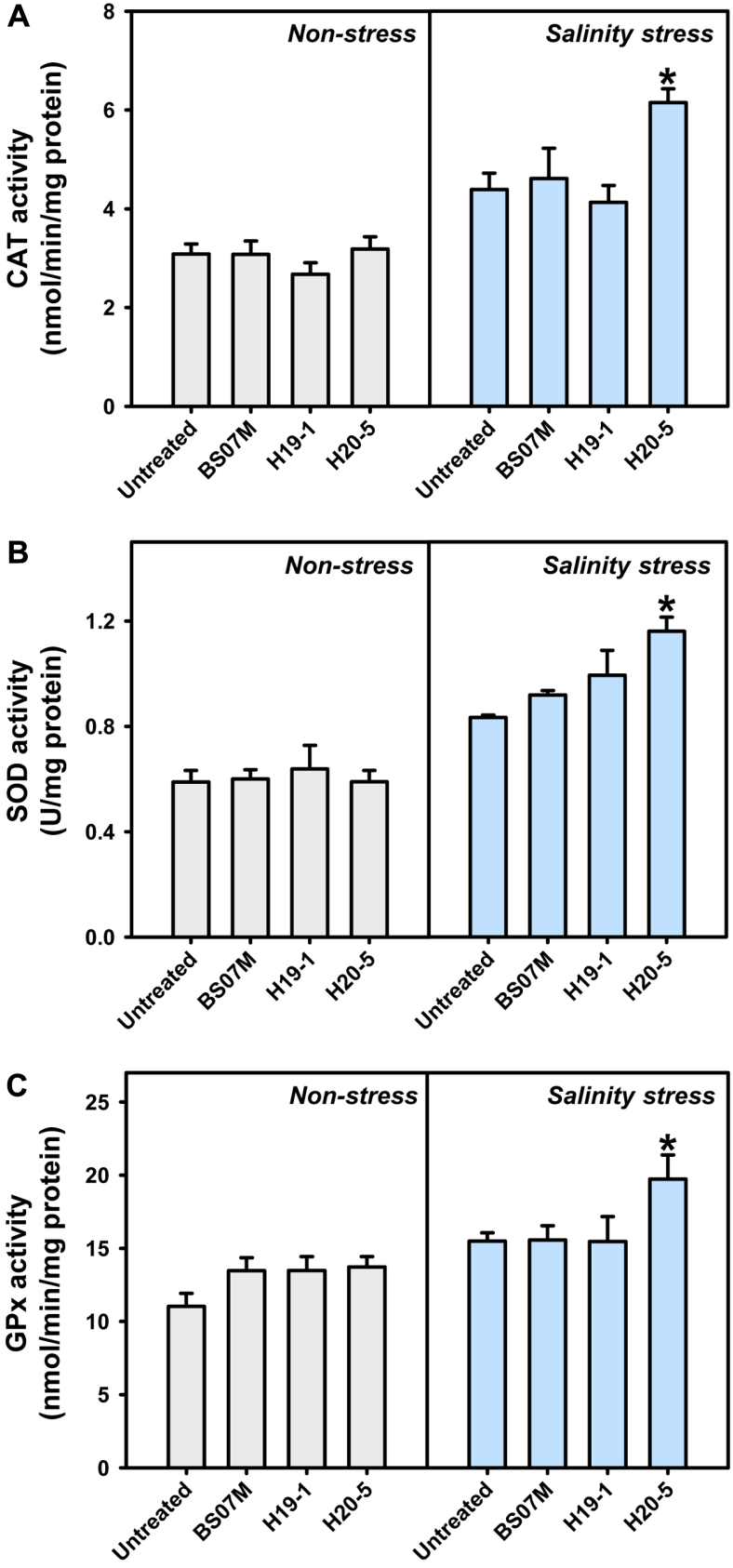

Treatment

Fig. 4. The effects of B. aryabhattai $\mathrm{H} 19-1$ and B. mesonae $\mathrm{H} 20-5$ on antioxidant enzyme activities including (A) CAT, (B) SOD, and (C) GPx in tomato leaves under non- and salinity stresses. Leaves were sampled at six days after salinity stress challenge. Asterisks on the bar mean significant difference by the LSD test at $p<$ 0.05 ; error bars indicate standard error.

glutathione peroxidase (GPx): $p=0.0003$ ). Antioxidant enzyme activity assays showed no significant difference 
Table 2. Proline, total soluble sugar and free amino acid contents in leaves of tomato plants treated with $10 \mathrm{mM} \mathrm{MgSO}_{4}$ (untreated) or bacterial suspensions under non- and salinity stresses.

\begin{tabular}{|c|c|c|c|c|c|c|}
\hline \multirow{2}{*}{ Treatment } & \multicolumn{2}{|c|}{ Proline (mg/g DW) } & \multicolumn{2}{|c|}{ Total soluble sugar $(\mathrm{mg} / \mathrm{g}$ DW) } & \multicolumn{2}{|c|}{ Total free amino acid $(\mu \mathrm{mol} / \mathrm{g}$ DW $)$} \\
\hline & Non-stress & Salinity stress & Non-stress & Salinity stress & Non-stress & Salinity stress \\
\hline Untreated & $0.62 \pm 0.19^{\mathrm{a}}$ & $59.85 \pm 2.08$ & $9.50 \pm 0.53$ & $4.36 \pm 0.29$ & $101.88 \pm 2.58$ & $61.20 \pm 1.14$ \\
\hline BS07M & $0.83 \pm 0.19$ & $61.05 \pm 3.31$ & $9.64 \pm 0.35$ & $4.59 \pm 0.25$ & $101.22 \pm 6.24$ & $59.93 \pm 2.18$ \\
\hline H19-1 & $0.79 \pm 0.18$ & $56.45 \pm 2.91$ & $9.84 \pm 0.20$ & $4.42 \pm 0.31$ & $106.52 \pm 3.19$ & $60.51 \pm 2.50$ \\
\hline $\mathrm{H} 20-5$ & $0.96 \pm 0.20$ & $69.15 \pm 3.43^{*}$ & $9.96 \pm 0.30$ & $4.70 \pm 0.22$ & $109.70 \pm 6.22$ & $58.40 \pm 1.66$ \\
\hline
\end{tabular}

a The values are mean \pm standard errors of 12 replications from two experiments. An asterisk indicates a statistical difference $(p<0.05)$ compared to untreated plants in a column by the LSD test.

between treatments under non-stressed condition (CAT: $p=0.4640$; SOD: $p=0.9147$; GPx: $p=0.1599$ ). However, $\mathrm{H} 20-5$ treatments significantly increased the activities of CAT (Fig. 4A), SOD (Fig. 4B) and GPx (Fig. 4C) compared to untreated plants under stressed condition whereas H19-1 $\operatorname{did} \operatorname{not}(\mathrm{CAT}: p=0.0116$; SOD: $p=0.0206$; GPx: $p=0.0253$ ).

\section{Strain H20-5 Regulates ABA Accumulation and ABA- Related Gene Expression in Tomato Plants under Salinity Stress}

To examine the effect of bacterial treatment on ABA metabolism in plants under salinity stress, ABA content and the expression levels of ABA-related genes including NCED1 and AREB1 were analyzed at 0,6 , and $24 \mathrm{~h}$ after stress challenge in plant leaves. H20-5-treated plants accumulated significantly higher levels of ABA than that in untreated and H19-1-treated plants at $24 \mathrm{~h}$ after salinity stress challenge. (Fig. 5, 0 HAS: $p=0.9679$; 6 HAS: $p=$ 0.3495 ; 24 HAS: $p=0.0055)$. Interestingly, bacterial strain H19-1 did not affect ABA content in leaves of tomato plants under salinity stress. In contrast to stressed plants, no striking difference was observed between untreated and bacteria-treated plants in the non-stressed condition $(0 \mathrm{~h}$ after stress challenge (HAS): $p=0.2267 ; 6$ HAS: $p=0.5718$; 24 HAS: $p=0.2220$ ). Relative gene expression of NCED1 and AREB1 had no significant difference between untreated and treated plants under non-stressed condition (Fig. 6, 0 HAS (NCED1): $p=0.1396 ; 6$ HAS (NCED1): $p=$ 0.0049; 24 HAS (NCED1): $p=0.3382 ; 0$ HAS (AREB1): $p=$ 0.1531; 6 HAS (AREB1): $p=0.0117 ; 24$ HAS (AREB1): $p=$ $0.7169)$. In stressed conditions, NCED1 gene expression level was increased in leaves of tomato plants treated with $\mathrm{H} 20-5$ at $6 \mathrm{~h}$ after stress challenge (Fig. 6A, $p=0.0168$ ); $A R E B 1$ gene expression was also seen to increase in leaves of plants treated with $\mathrm{H} 20-5$ at 6 and $24 \mathrm{~h}$ after the stress challenge (Fig. 6B, 6 HAS: $p=0.0001$; 24 HAS: $p<0.0001$ ). However, compared to untreated plants, H19-1 treatment led to a decrease in AREB1 gene expression level in plants at 6 and $24 \mathrm{~h}$ after stress challenge.

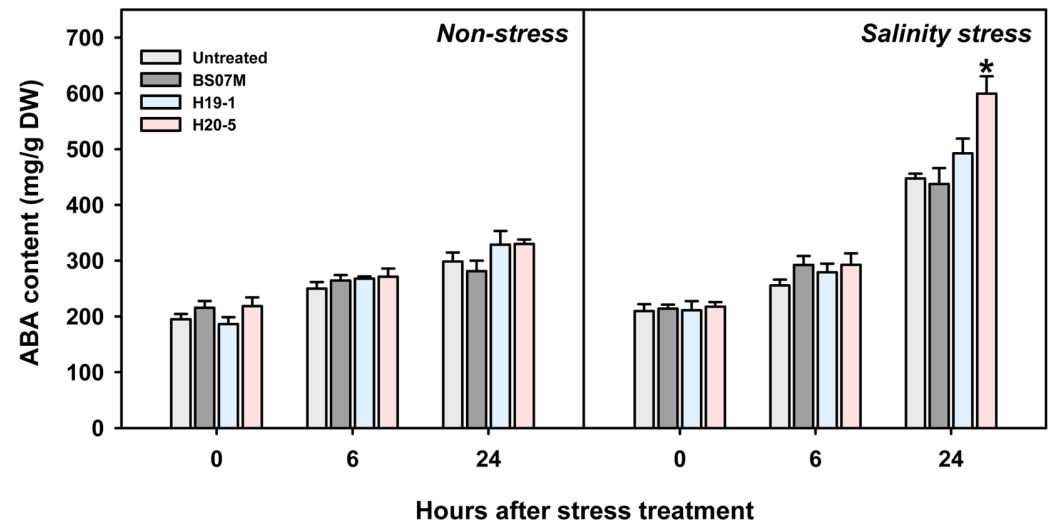

Fig. 5. The effects of B. aryabhattai H19-1 and B. mesonae H20-5 on ABA accumulation in tomato leaves under non- and salinity stresses.

Leaves were sampled at 0,6 , and $24 \mathrm{~h}$ after salinity stress challenge. Asterisks on the bar mean significant difference by the LSD test at $p<0.05$; error bars indicate standard error. 
A

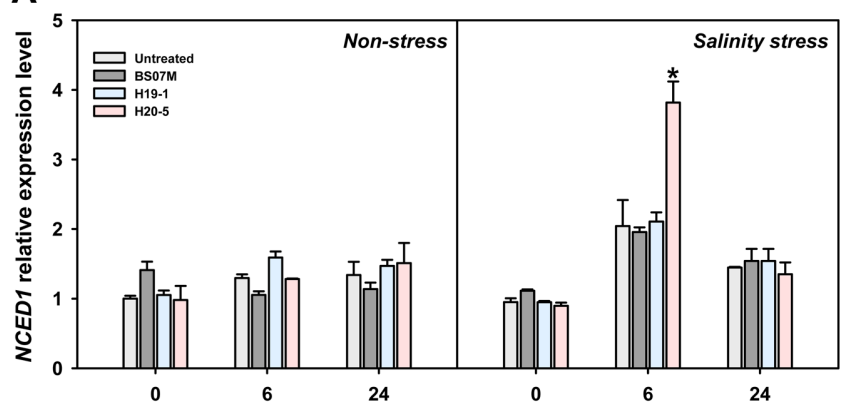

B

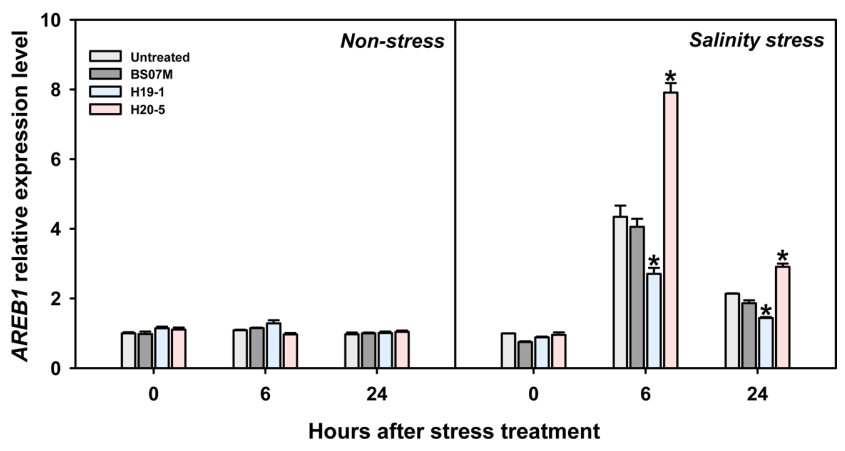

Fig. 6. The effects of B. aryabhattai H19-1 and B. mesonae H20-5 on gene expression level of (A) NCED1 and (B) AREB1 in tomato leaves under non- and salinity stresses.

Leaves were sampled at 0,6 , and $24 \mathrm{~h}$ after drenching water or salinity solution. Asterisks on the bar mean significant difference by the Tukey's test at $p<0.05$; error bars on the bar indicate standard error.

\section{Discussion}

To alleviate salinity stress in plants, beneficial bacterial strains such as PGPB and endophytic bacteria have been used to regulate plant abiotic stress tolerance $[35,36]$. In our previous study, two halotolerant bacterial strains, $B$. arryabhattai $\mathrm{H} 19-1$ and B. mesonae $\mathrm{H} 20-5$, were selected [37]. In this study, we demonstrated the changes in pigment content, electrolyte leakage, and $\mathrm{Ca}^{2+}$ content in tomato plants under salinity stress. Furthermore, we revealed that strain H20-5 regulated proline accumulation, antioxidant enzyme activities and ABA related metabolism in stressed plants.

Salinity stress decreases crop development and yield by down regulating photosynthesis including chlorophyll biosynthesis [38, 39]. Carotenoid can also regulate plant photosynthesis by helping in harvesting light and photoprotection $[40,41]$. In our study, fresh and dry weight as well as chlorophyll content in plants treated with H19-1 and H20-5 were increased compared to that in the control, whereas carotenoid content was increased in plants treated with H19-1 under salinity stress. These results indicated that the two bacterial strains regulate photosynthesis by increasing chlorophyll content; strain H19-1 protects carotenoid-related photosynthesis in plants under salinity stress. Similarly, earlier reports revealed that Sinorhizobium meliloti and Paenibacillus yonginensis help increase chlorophyll and carotenoid content under salinity stress in lucerne and ginseng plants, respectively [42, 43].

Electrolyte leakage is involved in programmed cell death and metabolic adjustment of plants under stresses such as salinity, drought, and pathogen attack; therefore, it was used as a parameter for assessing cell membrane stability [44, 45]. Both strains H19-1 and H20-5 decreased leaf electrolyte leakage compared to that in untreated plants under salinity stress. This result indicated the two bacterial strains help protect plants from cell membrane damage and enables them to adjust to salinity stress by regulating cell membrane function. Similarly, Serratia liquefaciens, Pseudomonas and Klebsiella sp. were reported to improve salinity stress tolerance by decreasing electrolyte leakage in plants [46-48]. Therefore, strains H19-1 and H20-5 enhance tolerance to salinity stress by decreasing electrolyte leakage in leaves of tomato plants.

Extreme $\mathrm{Na}^{+}$accumulation in plants can limit absorption, transport, and distribution of diverse mineral nutrients, and lead to nutrient imbalance in plants, e.g. decrease in $\mathrm{K}^{+}$ and $\mathrm{Ca}^{2+}$ content $[49,50]$. Moreover, accumulation of $\mathrm{Na}^{+}$ ion by root uptake induces $\mathrm{Na}^{+}$toxicity in the cytosol and disturbs the balance of $\mathrm{Na}^{+}$concentration in the vacuole of plants [51]. However, the two bacterial strains, H19-1 and $\mathrm{H} 20-5$, did not affect either $\mathrm{Na}^{+}$or $\mathrm{K}^{+}$content in nonstressed and stressed plants. This result could be caused by salinity solution components used in our study that comprised high concentrations of $\mathrm{KNO}_{3}, \mathrm{Ca}\left(\mathrm{NO}_{3}\right)_{2}, \mathrm{MgSO}_{4}$, and $\mathrm{KH}_{2} \mathrm{PO}_{4}$; therefore, accumulation of $\mathrm{Na}^{+}$did not occur in our systems and these may also not affect $\mathrm{K}^{+}$content in tomato leaves. $\mathrm{Ca}^{2+}$ content was decreased in plants under salinity stress, however, H19-1 and H20-5 accumulated higher levels of $\mathrm{Ca}^{2+}$ in leaves compared to those in untreated plants. Intracellular $\mathrm{Ca}^{2+}$ acts as a second messenger in stress perception and plays an important role in response to salinity stress by modulating the SOS signal transduction cascade which regulates ion homeostasis $[52,53]$. In addition, $\mathrm{Ca}^{2+}$ accumulation was involved in osmoregulation ability by increasing proline and improving the efficiency of water 
uptake under abiotic stress conditions [1, 54]. As a result, strains H19-1 and H20-5 induced salinity tolerance in tomato plants by $\mathrm{Ca}^{2+}$ accumulation.

Salinity stress has been reported to encourage proline accumulation for cell osmotic adjustment and membrane stabilization by regulating proline biosynthesis in plants [55]. Proline contributes to better chlorophyll protection, increase in water use efficiency, and protection of antioxidant enzymes [56]. In present study, only strain H20-5-treated plants exhibited a higher level of proline content than that in untreated plants. Similarly, Enterobacter cloacae strain increased proline content in canola plants under salinity stress [57]. Strains Bacillus subtilis and Arthrobacter sp. also confer salinity tolerance in wheat plants by increasing leaf proline content [58]. Therefore, accumulation of proline by $\mathrm{H} 20-5$ is one of the induced tolerance mechanisms in tomato plants under our salinity stress system. Total soluble sugar and free amino acids in plants also play an important role in osmoprotection and adjustment to salinity stress by conferring desiccation resistance to plant cells, and thus, help prevent plant growth inhibition in stressed conditions $[59,60]$. However, total soluble sugar and free amino acid did not accumulate under salinity stress in plants treated with bacterial strains. This result might indicate that induced salinity tolerance by strains H19-1 and H20-5 was not related to accumulation of total soluble sugars and free amino acids among a variety of plant osmolytes in our salinity system.

Plants have antioxidant defense systems including enzymes, which scavenge ROS in plant cells [61]. Salinity leads to overproduction of ROS including superoxide, hydroxyl ion, and singlet oxygen that cause damage to the membrane lipid and protein and the structure of the cell by membrane oxidation and thereby disrupt membrane semipermeability and water uptake mechanisms $[62,63]$. It is known that SOD, one of the antioxidant enzymes, induces the dismutation of superoxide to oxygen and hydrogen peroxide and CAT and GPx coordinated with SOD play a significant role in scavenging hydrogen peroxide, thereby providing protection, and leading to salinity stress tolerance [64]. Strain H20-5 improved SOD, CAT, and GPx activities under salinity stress whereas no significant effect was observed in non-stressed plants. Recently, similar results were reported, where beneficial microbes induced salinity tolerance by improving antioxidant enzyme activities in plants [65, 66]. Accordingly, H20-5 augments antioxidant enzyme activities and activation of the ROS scavenging process for enhancing tolerance to salinity stress in tomato plants.
ABA is well known as one of the phytohormones that is involved in signal pathways against abiotic stress. When plants encounter salinity stress, $\mathrm{ABA}$ in plants regulates the vacuolar $\mathrm{Na}^{+} / \mathrm{H}^{+}$antiporter gene related to ion homeostasis in cells and stress-response genes, such as RD29A, RAB18 and P5CS [67, 68]. Furthermore, ABA has been demonstrated to modulate transpiration in plants by increasing water influx into roots and controlling stomatal closure in leaves to adjust abiotic stress response [69, 70]. Recently, Bacillus licheniformis, Azospirillum sp. and Pseudomonas sp. were reported to induce salinity stress tolerance in plants through enhancement of ABA content in leaves [71, 72]. Similarly, only strain H20-5 increased ABA content compared to that in untreated plants at $24 \mathrm{~h}$ after the salinity stress challenge. This might mean H20-5 conferred induced-tolerance to salinity stress by inducing ABA accumulation in plants. Furthermore, relative expression level of the NCED1 gene in plants treated with H20-5 was higher than that in untreated plants under salinity stress at $6 \mathrm{~h}$ after the salinity stress challenge. The enzyme 9-cisepoxycarotenoid dioxygenase (NCED) is key in the biosynthesis of ABA in plants [73]; the NCED encoded gene induced by abiotic stresses, led to ABA accumulation; overexpression of the NCED gene caused over-production of $\mathrm{ABA}$, and enhanced abiotic stress tolerance [74, 75]. The abscisic acid-response elementbinding proteins (AREBs), bZIP transcriptional factors, are known to mediate the gene activation pathway related to abiotic stress tolerance by recognition of ABA hormones in plants [76, 77]. Hsieh et al. [78] and Orellana et al. [79] have reported that AREB1 is involved in ABA signals and confers salinity and drought stress tolerance by regulating ABA-dependent stress response genes. Interestingly, H20-5 increased AREB1 gene expression level whereas H19-1 decreased it in tomato plants at 6 and $24 \mathrm{~h}$ after the salinity stress challenge. These results indicated that $\mathrm{H} 20-5$ led to upregulation of $A R E B 1$ gene expression to confer salinity stress tolerance, whereas H19-1 caused downregulation of the same, presumably facilitating adaptation to the stressed condition. Accordingly, H20-5 regulated ABA metabolism including $A B A$ accumulation and expression of $A B A-$ related genes, NCED1 and AREB1 to tolerate salinity stress in tomato plants.

Briefly, we demonstrated the effects of bacterial strains Bacillus aryabhattai $\mathrm{H} 19-1$ and B. mesonae $\mathrm{H} 20-5$ on induced tolerance to salinity stress in tomato plants (Fig. 7). The findings revealed that H19-1 and H20-5 could ameliorate salinity stress damage in plants by inducing ABAindependent and -dependent tolerance, respectively. We 


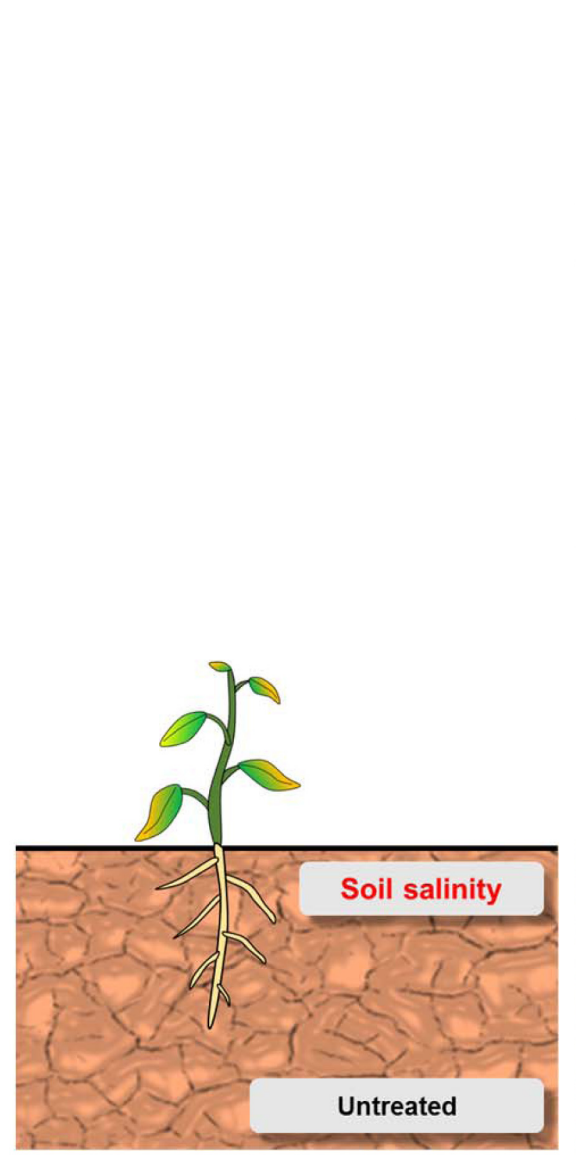

\section{Induced tolerance to salinity stress}
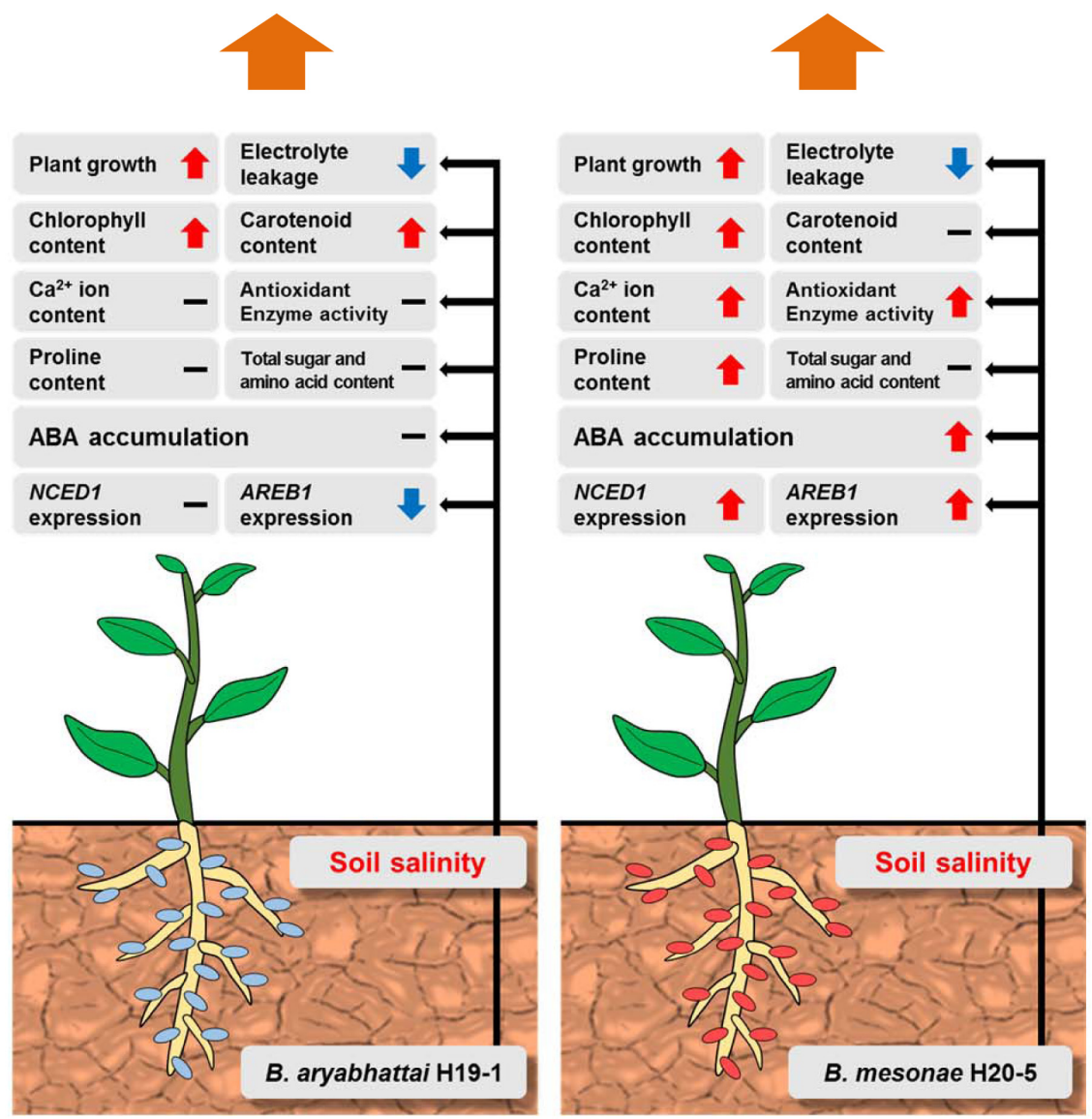

Fig. 7. Overview of mode of action of B. aryabhattai H19-1 and B. mesonae H20-5 for induced-tolerance to salinity stress in tomato plants.

The two bacterial strains improve plant growth, chlorophyll and $\mathrm{Ca}^{2+}$ ion accumulation and reduce electrolyte leakage in plant leaves. In addition, B. mesonae H20-5 lead to an increase of antioxidant enzyme activities including CAT, SOD, and GPx; ABA accumulation; upregulate two genes, NCED1 and AREB1 in tomato plants. On the contrary, B. aryabhattai H19-1 downregulate AREB1 gene expression. The red and blue colored arrows indicate the increase and decrease of tested factors, respectively, in tomato plants.

propose that these two strains can be used as effective biofertilizer for sustainable agriculture by enhancement of plant tolerance to salinity stress.

\section{Acknowledgment}

This work was supported by the National Institute of Agricultural Science (Project No. PJ011850) of the Rural Development Administration, Republic of Korea.

\section{Conflict of Interest}

The authors have no financial conflicts of interest to declare.

\section{References}

1. Bano A, Fatima M. 2009. Salt tolerance in Zea mays (L). following inoculation with Rhizobium and Pseudomonas. Biol. Fert. Soils 45: 405-413.

2. Jha Y, Subramanian RB, Patel S. 2011. Combination of endophytic and rhizospheric plant growth promoting rhizobacteria in Oryza sativa shows higher accumulation of osmoprotectant against saline stress. Acta Physiol. Plant. 33: 797-802.

3. Munns R, Gilliham M. 2015. Salinity tolerance of crops what is the cost? New Phytol. 208: 668-673.

4. Ruan CJ, da Silva JAT, Mopper S, Qin P, Lutts S. 2010. Halophyte improvement for a salinized world. Crit. Rev. Plant Sci. 29: 329-359. 
5. Lakhdar A, Rabhi M, Ghnaya T, Montemurro F, Jedidi N, Abdelly C. 2009. Effectiveness of compost use in saltaffected soil. J. Hazard Mater. 171: 29-37.

6. Tester M, Langridge P. 2010. Breeding technologies to increase crop production in a changing world. Science 327: 818-822.

7. Moreno-Limon S, Maiti RK, Nunez-Gonzalez A, Star JV, Foroughbakhch R, Gamez-Gonzalez H. 2000. Genotypic variability in bean cultivars (Phaseolus vulgaris L.) for resistance to salinity at the seedling stage. Ind. Agric. 44: 1-12.

8. Mano Y, Takeda K. 2001. Genetic resources of salt tolerance at germination and the seedling stage in wheat. Jpn. J. Crop. Sci. 70: 215-220.

9. Athar H, Ashraf M. 2009. Strategies for crop improvement against salinity and drought stress: an overview. In Salinity and Water Stress. pp. 1-16: Springer.

10. Li HW, Zang BS, Deng XW, Wang XP. 2011. Overexpression of the trehalose-6-phosphate synthase gene OsTPS1 enhances abiotic stress tolerance in rice. Planta 234: 1007-1018.

11. Muñoz-Mayor A, Pineda B, Garcia-Abellán JO, Antón T, Garcia-Sogo B, Sanchez-Bel P, et al. 2012. Overexpression of dehydrin tas14 gene improves the osmotic stress imposed by drought and salinity in tomato. J. Plant Physiol. 169: 459468.

12. Chen L, Liu Y, Wu G, Veronican Njeri K, Shen Q, Zhang N, et al. 2016. Induced maize salt tolerance by rhizosphere inoculation of Bacillus amyloliquefaciens SQR9. Physiol. Plant. 158: $34-44$.

13. Bhardwaj D, Ansari MW, Sahoo RK, Tuteja N. 2014. Biofertilizers function as key player in sustainable agriculture by improving soil fertility, plant tolerance and crop productivity. Microb. Cell Fact. 13: 66.

14. Esitken A, Yildiz HE, Ercisli S, Donmez MF, Turan M, Gunes A. 2010. Effects of plant growth promoting bacteria (PGPB) on yield, growth and nutrient contents of organically grown strawberry. Sci. Hortic. 124: 62-66.

15. Fernandez O, Theocharis A, Bordiec S, Feil R, Jacquens, L Clément C, et al. 2012. Burkholderia phytofirmans PsJN acclimates grapevine to cold by modulating carbohydrate metabolism. Mol. Plant Microbe Interact. 25: 496-504.

16. Jha Y, Subramanian RB. 2014. PGPR regulate caspase-like activity, programmed cell death, and antioxidant enzyme activity in paddy under salinity. Physiol. Mol. Biol. Plants 20: 201-207.

17. Meena RK, Singh RK, Pal Singh N, Meena SK, Meena VS. 2015. Isolation of low temperature surviving plant growth promoting rhizobacteria (PGPR) from pea (Pisum sativum L.) and documentation of their plant growth promoting traits. Biocatal. Agric. Biotechnol. 4: 806-811.

18. Glick BR. 2014. Bacteria with ACC deaminase can promote plant growth and help to feed the world. Microbiol. Res. 169: 30-39.
19. Damodaran T, Sah V, Rai RB, Sharma DK, Mishra VK, Jha SK, et al. 2013. Isolation of salt tolerant endophytic and rhizospheric bacteria by natural selection and screening for promising plant growth-promoting rhizobacteria (PGPR) and growth vigour in tomato under sodic environment. Afr. J. Microbiol. Res. 7: 5082-5089.

20. Qu L, Huang, Y, Zhu C, Zeng H, Shen C, Liu C, et al. 2015. Rhizobia-inoculation enhances the soybean's tolerance to salt stress. Plant Soil 400: 209-222.

21. Bharti N, Pandey SS, Barnawal D, Patel VK, Kalra A. 2016. Plant growth promoting rhizobacteria Dietzia natronolimnaea modulates the expression of stress responsive genes providing protection of wheat from salinity stress. Sci. Rep. 6: 34768 .

22. Yang J, Kloepper JW, Ryu CM. 2009. Rhizosphere bacteria help plants tolerate abiotic stress. Trends Plant Sci. 14: 1-4.

23. Sang MK, Dutta S, Park K. 2015. Influence of commercial antibiotics on biocontrol of soft rot and plant growth promotion in Chinese cabbages by Bacillus vallismortis EXTN-1 and BS07M. Res. Plant Dis. 21: 225-260.

24. Polonenko DR, Mayfield CI, Dumbroff EB. 1981. Microbial responses to salt-induced osmotic stress. Plant Soil 59: 269285.

25. Lichtenthaler HK. 1987. Chlorophyll fluorescence signatures of leaves during the autumnal chlorophyll breakdown. $J$. Plant Physiol. 131: 101-110.

26. Lutts S, Kinet JM, Bouharmont J. 1996. NaCl-induced senescence in leaves of rice (Oryza sativa L.) cultivars differing in salinity resistance. Ann. Bot. 78: 389-398.

27. Shukla PS, Agarwal PK, Jha B. 2012. Improved salinity tolerance of Arachis hypogaea (L.) by the interaction of halotolerant plant-growth-promoting rhizobacteria. J. Plant Growth Regul. 31: 195-206.

28. Iseki K, Marubodee R, Ehara H, Tomooka N. 2017. A rapid quantification method for tissue $\mathrm{Na}^{+}$and $\mathrm{K}^{+}$concentrations in salt-tolerant and susceptible accessions in Vigna vexillata (L.) A. Rich. Plant Prod. Sci. 20: 144-148.

29. Bates LS, Waldren RP, Teare I. 1973. Rapid determination of free proline for water-stress studies. Plant Soil 39: 205-207.

30. Yemm EW, Willis AJ. 1954. The estimation of carbohydrates in plant extracts by anthrone. Biochem. J. 57: 508-514.

31. Chen Z, Cuin TA, Zhou M, Twomey A, Naidu BP, Shabala S. 2007. Compatible solute accumulation and stress-mitigating effects in barley genotypes contrasting in their salt tolerance. J. Exp. Bot. 58: 4245-4255.

32. Iovieno P, Punzo P, Guida G, Mistretta C, Van Oosten MJ, Nurcato R, et al. 2016. Transcriptomic changes drive physiological responses to progressive drought stress and rehydration in tomato. Front. Plant Sci. 7: 371.

33. Løvdal T, Lillo C. 2009. Reference gene selection for quantitative real-time PCR normalization in tomato subjected to nitrogen, cold, and light stress. Anal. Biochem. 387: 238-242. 
34. Livak KJ, Schmittgen TD. 2001. Analysis of relative gene expression data using real-time quantitative PCR and the 2(Delta Delta C(T)) Method. Methods 25: 402-408.

35. Halo BA, Khan AL, Waqas M, Al-Harrasi A, Hussain J, Ali L, et al. 2015. Endophytic bacteria (Sphingomonas sp. LK11) and gibberellin can improve Solanum lycopersicum growth and oxidative stress under salinity. J. Plant Interact. 10: 117-125.

36. Chatterjee P, Samaddar S, Anandham R, Kang Y, Kim K, Selvakumar G, et al. 2017. Beneficial soil bacterium Pseudomonas frederiksbergensis OS261 augments salt tolerance and promotes red pepper plant growth. Front. Plant Sci. 8: 705.

37. Yoo SJ, Shin DJ, Weon HY, Song J, Sang MK. 2018. Selection of bacteria for enhancement of tolerance to salinity and temperature stresses in tomato plants. Korean J. Org. Agric. 26: 463-475.

38. Turan S, Tripathy BC. 2015. Salt-stress induced modulation of chlorophyll biosynthesis during de-etiolation of rice seedlings. Physiol. Plant. 153: 477-491.

39. Kalaji HM, Jajoo A, Oukarroum A, Brestic M, Zivcak M, Samborska IA, et al. 2016. Chlorophyll a fluorescence as a tool to monitor physiological status of plants under abiotic stress conditions. Acta Physiol. Plant. 38: 102.

40. Amirjani MR. 2011. Effect of salinity stress on growth, sugar content, pigments and enzyme activity of rice. Int. J. Bot. 7: 73-81.

41. Ruiz-Sola MÁ, Arbona V, Gómez-Cadenas A, RodríguezConcepción M, Rodríguez-Villalón A. 2014. A root specific induction of carotenoid biosynthesis contributes to ABA production upon salt stress in Arabidopsis. PLoS One 9: e90765.

42. Baha N, Bekki A. 2015. An approach of improving plant salt tolerance of Lucerne (Medicago sativa) grown under salt stress: use of Bio-inoculants. J. Plant Growth. Regul. 34: 169182.

43. Sukweenadhi J, Balusamy SR, Kim YJ, Lee CH, Kim YJ, Koh SC, et al. 2018. A growth-promoting bacteria, Paenibacillus yonginensis $\mathrm{DCY} 84^{\mathrm{T}}$ enhanced salt stress tolerance by activating defense-related systems in Panax ginseng. Front. Plant Sci. 9: 813.

44. Bajji M, Kinet JM, Lutts S. 2001. The use of the electrolyte leakage method for assessing cell membrane stability as a water stress tolerance test in durum wheat. Plant Growth Regul. 36: 61-70.

45. Demidchik V, Straltsova D, Medvedev SS, Pozhvanov GA, Sokolik A, Yurin V. 2014. Stress-induced electrolyte leakage: the role of $\mathrm{K}^{+}$-permeable channels and involvement in programmed cell death and metabolic adjustment. J. Exp. Bot. 65: 1259-1270.

46. El-Esawi MA, Alaraidh IA, Alsahli AA, Alzahrani SM, Ali HM, Alayafi AA, et al. 2018. Serratia liquefaciens KM4 improves salt stress tolerance in maize by regulating redox potential, ion homeostasis, leaf gas exchange and stressrelated gene expression. Int. J. Mol. Sci. 19(11): pii.3310.

47. Rabhi NEH, Silini A, Cherif-Silini H, Yahiaoui B, Lekired A, Robineau M, et al. 2018. Pseudomonas knackmussii MLR6, a rhizospheric strain isolated from halophyte, enhances salt tolerance in Arabidopsis thaliana. J. Appl. Microbiol. 125: 18361851.

48. Sapre S, Gontia-Mishra I, Tiwari S. 2018. Klebsiella sp. confers enhanced tolerance to salinity and plant growth promotion in oat seedlings (Avena sativa). Microbiol. Res. 206: 25-32.

49. Singh RP, Jha P, Jha PN. 2015. The plant-growth-promoting bacterium Klebsiella sp. SBP-8 confers induced systemic tolerance in wheat (Triticum aestivum) under salt stress. $J$. Plant physiol. 184: 57-67.

50. Sharma S, Kulkarni J, Jha B. 2016. Halotolerant rhizobacteria promote growth and enhance salinity tolerance in peanut. Front. Microbiol. 7: 1600.

51. Shabala S, Shabala S, Cuin TA, Pang J, Percey W, Chen Z, et al. 2010. Xylem ionic relations and salinity tolerance in barley. Plant J. 61: 839-853.

52. Quan R, Lin H, Mendoza I, Zhang Y, Cao W, Yang Y, et al. 2007. SCABP8/CBL10, a putative calcium sensor, interacts with the protein kinase SOS2 to protect Arabidopsis shoots from salt stress. Plant Cell 19: 1415-1431.

53. Ranty B, Aldon D, Cotelle V, Galaud JP, Thuleau P, Mazars C. 2016. Calcium sensors as key hubs in plant responses to biotic and abiotic stresses. Front. Plant Sci. 7: 327.

54. Nayyar H. 2003. Variation in osmoregulation in differentially drought-sensitive wheat genotypes involves calcium. Biol. Plant. 47: 541-547.

55. Huang Z, Zhao L, Chen D, Liang M, Liu Z, Shao H, et al. 2013. Salt stress encourages proline accumulation by regulating proline biosynthesis and degradation in Jerusalem artichoke plantlets. PLoS One 8: e62085.

56. Reddy PS, Jogeswar G, Rasineni GK, Maheswari M, Reddy AR, Varshney RK, et al. 2015. Proline over-accumulation alleviates salt stress and protects photosynthetic and antioxidant enzyme activities in transgenic sorghum [Sorghum bicolor (L.) Moench]. Plant Physiol. Biochem. 94: 104-113.

57. Li H, Lei P, Pang X, Li S, Xu H, Xu Z, et al. 2017. Enhanced tolerance to salt stress in canola (Brassica napus L.) seedlings inoculated with the halotolerant Enterobacter cloacae HSNJ4. Appl. Soil Ecol. 119: 26-34.

58. Upadhyay SK, Singh JS, Saxena AK, Singh DP. 2012. Impact of PGPR inoculation on growth and antioxidant status of wheat under saline conditions. Plant Biol. 14: 605-611.

59. Kerepesi I, Galiba G. 2000. Osmotic and salt stress-induced alteration in soluble carbohydrate content in wheat seedlings. Crop. Sci. 40: 482-487.

60. Singh RP, Jha PN. 2016. A halotolerant bacterium Bacillus licheniformis HSW-16 augments induced systemic tolerance 
to salt stress in wheat plant (Triticum aestivum). Front. Plant Sci. 7: 1890 .

61. Das K and Roychoudhury A. 2014. Reactive oxygen species (ROS) and response of antioxidants as ROS-scavengers during environmental stress in plants. Front. Environ. Sci. 2.

62. Munns R, Tester M. 2008. Mechanisms of salinity tolerance. Annu. Rev. Plant Biol. 59: 651-681.

63. Hussain S, Khaliq A, Matloob A, Wahid MA, Afzal I. 2013. Germination and growth response of three wheat cultivars to $\mathrm{NaCl}$ salinity. Soil Environ. 32: 36-43.

64. Azevedo-Neto AD, Prisco JT, Enéas-Filho J, de Abreu CEB, Gomes-Filho E. 2006. Effect of salt stress on antioxidative enzymes and lipid peroxidation in leaves and roots of salttolerant and salt-sensitive maize genotypes. Environ. Exp. Bot. 56: 87-94.

65. Islam F, Yasmeen T, Arif MS, Ali S, Ali B, Hameed S, et al. 2016. Plant growth promoting bacteria confer salt tolerance in Vigna radiata by up-regulating antioxidant defense and biological soil fertility. Plant Growth Regul. 80: 23-36.

66. Akram MS, Shahid M, Tariq M, Azeem M, Javed MT, Saleem S, et al. 2016. Deciphering Staphylococcus sciuri SAT17 mediated anti-oxidative defense mechanisms and growth modulations in salt stressed maize (Zea mays L.). Front. Microbiol. 7: 867.

67. Shi H, Zhu JK. 2002. Regulation of expression of the vacuolar $\mathrm{Na}^{+} / \mathrm{H}^{+}$antiporter gene AtNHX1 by salt stress and abscisic acid. Plant Mol. Biol. 50: 543-550.

68. Saavedra X, Modrego A, Rodríguez D, González-García MP, Sanz L, Nicolás G, et al. 2010. The nuclear interactor PYL8/ RCAR3 of Fagus sylvatica FsPP2C1 is a positive regulator of abscisic acid signaling in seeds and stress. Plant Physiol. 152: 133-150.

69. Gómez-Cadenas A, Arbona V, Jacas J, Primo-Millo E, Talon M. 2003. Abscisic acid reduces leaf abscission and increases salt tolerance in citrus plants. J. Plant Growth Regul. 21: 234-240.

70. Yoshida R, Umezawa T, Mizoguchi T, Takahashi S, Takahashi F, Shinozaki K. 2006. The regulatory domain of SRK2E/OST1/SnRK2.6 interacts with ABI1 and integrates abscisic acid (ABA) and osmotic stress signals controlling stomatal closure in Arabidopsis. J. Biol. Chem. 281: 5310-5318.
71. Naz R, Bano A. 2015. Molecular and physiological responses of sunflower (Helianthus annuus L.) to PGPR and SA under salt stress. Pak. J. Bot. 47: 35-42.

72. Zhou C, Zhu L, Xie,Y, Li F, Xiao X, Ma Z, et al. 2017. Bacillus licheniformis SA03 confers increased saline-alkaline tolerance in chrysanthemum plants by induction of abscisic acid accumulation. Front. Plant Sci. 8: 1143.

73. Sun L, Sun Y, Zhang M, Wang L, Ren J, Cui M, et al. 2012. Suppression of 9-cis-epoxycarotenoid dioxygenase, which encodes a key enzyme in abscisic acid biosynthesis, alters fruit texture in transgenic tomato. Plant Physiol. 158: 283-298.

74. Iuchi S, Kobayashi M, Yamaguchi-Shinozaki K, Shinozaki K. 2000. A stress-inducible gene for 9-cis-epoxycarotenoid dioxygenase involved in abscisic acid biosynthesis under water stress in drought-tolerant cowpea. Plant Physiol. 123: 553-562.

75. Thompson AJ, Jackson AC, Symonds RC, Mulholland BJ, Dadswell AR, Blake PS, et al. 2000. Ectopic expression of a tomato 9-cis-epoxycarotenoid dioxygenase gene causes overproduction of abscisic acid. Plant J. 23: 363-374.

76. Uno Y, Furihata T, Abe H, Yoshida R, Shinozaki K, Yamaguchi-Shinozaki K. 2000. Arabidopsis basic leucine zipper transcription factors involved in an abscisic aciddependent signal transduction pathway under drought and high-salinity conditions. Proc. Natl. Acad. Sci. USA 97: 1163211637.

77. Yanez M, Caceres S, Orellana S, Bastias A, Verdugo I, RuizLara S, et al. 2009. An abiotic stress-responsive bZIP transcription factor from wild and cultivated tomatoes regulates stress-related genes. Plant Cell Rep. 28: 1497-1507.

78. Hsieh TH, Li CW, Su RC, Cheng CP, Sanjaya, Tsai YC, Chan MT. 2010. A tomato bZIP transcription factor, SlAREB, is involved in water deficit and salt stress response. Planta 231: 1459-1473.

79. Orellana S, Yañez M, Espinoza A, Verdugo I, Gonzalez E, Ruiz-Lara S, et al. 2010. The transcription factor SlAREB1 confers drought, salt stress tolerance and regulates biotic and abiotic stress-related genes in tomato. Plant cell Environ. 33: 2191-2208. 